\title{
Antimicrobial and cytotoxic activity of fungal mycelial extracts from aquatic environments in the Amazon
}

Atividade antimicrobiana e citotóxica de extratos miceliais de fungos de ambientes aquáticos da Amazônia

\section{Actividad antimicrobiana y citotóxica de extractos miceliales de hongos de ambientes acuáticos en}

\section{la Amazonía}

\author{
Marta Rodrigues de Oliveira \\ ORCID: https://orcid.org/0000-0002-6065-7480 \\ Universidade Federal do Amazonas, Brazil \\ E-mail: mro.dbb@uea.edu.br \\ Sarah Raquel Silveira da Silva Santiago \\ ORCID: https://orcid.org/0000-0002-6943-8436 \\ Universidade Federal do Amazonas, Brazil \\ E-mail: srhraquel@gmail.com \\ Ricardo de Melo Katak \\ ORCID: https://orcid.org/0000-0001-5318-4884 \\ Universidade Federal do Amazonas, Brazil \\ E-mail: ricardokatak@gmail.com \\ Marlene Rodrigues Marcelino Camargo \\ ORCID: https://orcid.org/0000-0002-0953-8507 \\ Universidade Federal do Amazonas, Brazil \\ E-mail: marlene.camrr@gmail.com \\ Ivanildes dos Santos Bastos \\ ORCID: https://orcid.org/0000-0001-8333-6885 \\ Instituto Leônidas e Maria Deane-Fiocruz Amazônia, Brazil \\ E-mail: ivanildessantos21@hotmail.com \\ Patrícia Puccinelli Orlandi \\ ORCID: https://orcid.org/0000-0003-2104-577X \\ Instituto Leônidas e Maria Deane-Fiocruz Amazônia, Brazil \\ E-mail: patricia.orlandi@fiocruz.br \\ Wanderli Pedro Tadei \\ ORCID: https://orcid.org/0000-0002-0612-3285 \\ Instituto Nacional de Pesquisas da Amazônia, Brazil \\ $\Phi$ in memoriam \\ Afonso Duarte Leão de Souza \\ ORCID: https://orcid.org/0000-0001-7007-3991 \\ Universidade Federal do Amazonas, Brazil \\ E-mail: souzadq@ufam.edu.br \\ Antonia Queiroz Lima de Souza \\ ORCID: https://orcid.org/0000-0001-5602-8617 \\ Universidade Federal do Amazonas, Brazil \\ E-mail: antoniaqueiroz@ufam.edu.br
}

\begin{abstract}
Fungi are a prolific source of biologically active metabolites, including a wide range of clinically important drugs. Therefore, this study aims to evaluate the antimicrobial and cytotoxic activity of secondary metabolites extracted from fungal mycelia isolated from freshwater samples in the state of Amazonas. Mycelial extracts from 12 fungal were used, extracted with MeOH/AcOEt (1:1) according to the criteria established by Souza et al. (2004). For antimicrobial activity, the extracts were tested against the pathogens Staphylococcus aureus, Escherichia coli, Pseudomonas aeruginosa, Enterococcus feacalis, Candida albicans and C. tropicalis. To identify the minimum inhibitory dosage (MID) the microdilution method was used. To perform the cytotoxicity assay, the VERO strain (ATCC® CCL81TM) was used. The assays were determined by the Alamar Blue method according to Ahmed et al. (1994). The tested extracts did not show antibacterial activity. Five extracts (41.7\%), obtained from the fungi Aspergillus - 1283, Chrysoporther - 1169, Diaporther - 1203, Fusarium - 1085, and Trichoderma, showed antifungal activity against $C$. albicans. Diaporther extract (8.3\%) - 1203 was active against C. tropicalis. In the cytotoxicity assay, 58.3\% of the evaluated extracts showed no significant toxic effect. Five extracts, Cladosporium - 1135, Chrysoporther - 1169,
\end{abstract}


Cytospora - 1098, Fusarium - 1085, and Talaromyces - 1244, showed cytotoxic potential, exhibiting viability lower than $70 \%$. The results obtained suggest that mycelial extracts of fungi isolated from water samples from the Amazon region have potential against yeasts of medical interest. Only two of the active extracts were revealed potentially cytotoxic.

Keywords: Antifungal activity; Cytotoxicity; Bioactive metabolites.

\section{Resumo}

Os fungos são uma fonte prolífica de metabólitos biologicamente ativos, incluindo uma ampla gama de drogas clinicamente importantes. Portanto, este estudo tem como objetivo avaliar a atividade antimicrobiana e citotóxica de metabólitos secundários extraídos de micélios fúngicos isolados de amostras de água doce do estado do Amazonas. Foram utilizados extratos miceliais de 12 fungos, extraídos com MeOH/ AcOEt (1:1) de acordo com os critérios estabelecidos por Souza et al. (2004). Para atividade antimicrobiana, os extratos foram testados contra os patógenos Staphylococcus aureus, Escherichia coli, Pseudomonas aeruginosa, Enterococcus feacalis, Candida albicans e C. tropicalis. Para identificar a dosagem inibitória mínima (MID) foi utilizado o método de microdiluição. Para a realização do ensaio de citotoxicidade, foi utilizada a cepa VERO (ATCC® CCL-81TM). Os ensaios foram determinados pelo método Alamar Blue de acordo com Ahmed et al. (1994). Os extratos testados não apresentaram atividade antibacteriana. Cinco extratos (41,7\%), obtidos dos fungos Aspergillus - 1283, Chrysoporther - 1169, Diaporther - 1203, Fusarium - 1085 e Trichoderma, apresentaram atividade antifúngica contra C. albicans. O extrato de Diaporther (8,3\%) - 1203 foi ativo contra C. tropicalis. No ensaio de citotoxicidade, 58,3\% dos extratos avaliados não apresentaram efeito tóxico significativo e cinco extratos, Cladosporium - 1135, Chrysoporther - 1169, Cytospora - 1098, Fusarium - 1085 e Talaromyces - 1244, apresentaram potencial citotóxico exibindo viabilidade menor que $70 \%$. Os resultados obtidos sugerem que extratos miceliais de fungos isolados de amostras de água da região amazônica apresentam potencial contra leveduras de interesse médico. Apenas dois dos extratos ativos foram potencialmente citotóxicos.

Palavras-chave: Atividade antifúngica; Citotoxicidade; Metabólitos bioativos.

\section{Resumen}

Los hongos son una fuente prolífica de metabolitos biológicamente activos, incluida una amplia gama de fármacos clínicamente importantes. Así, el objetivo de este estudio fue evaluar la actividad antimicrobiana y citotóxica de metabolitos secundários extraídos de micelios fúngicos aislados de muestras de agua en el estado de Amazonas. Se utilizaron extractos miceliales de 12 hongos, extraídos con MeOH/ AcOEt (1:1) según los criterios establecidos por Souza et al. (2004). En la prueba antimicrobiana, los extractos fueron evaluados frente a los patógenos Staphylococcus aureus, Escherichia coli, Pseudomonas aeruginosa, Enterococcus feacalis, Candida albicans y C. tropicalis. Para identificar la dosis mínima inhibitoria (MID) se utilizó el método de microdilución. Para realizar el ensayo de citotoxicidad se utilizó la cepa VERO (ATCC® CCL-81TM). Los ensayos se determinaron mediante el método Alamar Blue según Ahmed et al. (1994). Los extractos probados no mostraron actividad antibacteriana. Cinco (41,7\%) extractos obtenidos de los hongos Aspergillus - 1283, Chrysoporther - 1169, Diaporther - 1203, Fusarium 1085 y Trichoderma, mostraron actividad antifúngica contra C. albicans y un extracto $(8,3 \%)$ del hongo Diaporther 1203 fue activo contra $C$. tropicalis. En el ensayo de citotoxicidad, el 58,3\% de los extractos evaluados no mostraron ningún efecto tóxico significativo y cinco extractos, Cladosporium - 1135, Chrysoporther - 1169, Cytospora - 1098, Fusarium - 1085 y Talaromyces - 1244, mostraron potencial citotóxico com una viabilidad inferior al 70\%. Los resultados obtenidos sugieren que extractos miceliales de hongos aislados de muestras de agua de la región amazónica tienen potencial contra levaduras de interés médico. Solo dos de los extractos activos fueron potencialmente citotóxicos.

Palabras clave: Actividad antifúngica; Citotoxicidad; Metabolitos bioactivos.

\section{Introduction}

Antimicrobial resistance is a major public health problem worldwide and jeopardizes the effectiveness of preventing and treating an increasing number of infectious diseases caused by viruses, bacteria, fungi, and parasites according to the Pan American Health Organization (PAHO, 2020).

The need to control emerging diseases or resistant strains requires the constant search for new sources of antimicrobial compounds with new action mechanisms, not only for human use but also for use in livestock (Santos et al., 2015; Premjanu \& Jaynthy, 2015). Antimicrobials are natural or synthetic compounds capable of inhibiting or killing microorganisms through specific interactions with their targets, regardless of the compound source or its class (Davies \& Davies, 2010).

Currently, natural products and their derivatives are still the most important resources for new drugs discovery (Ayoub et al., 2014; Atanasov et al., 2021). Fungi are considered an important source of biologically active secondary 
metabolites, including a wide variety of clinically important drugs (Hoeksma et al., 2019). Fungi have a chemical and biological rich diversity. Historically they have given rise to many new drugs and may hold the key to dealing with emerging antimicrobial resistances.

Fungi are excellent producers of hydrolytic enzymes, biofuels, organic acids, polysaccharides, and secondary metabolites, such as antibiotics, anticancer drugs, hypocholesterolemic agents, immunosuppressants, among other (Sanchez \& Demain, 2017), which make them attractive for the discovery of new bioactive molecules with antimicrobial properties.

Given the economic and industrial importance of fungi, the aquatic environment is an important place to expand the discovery of new fungal species and new biological properties (Heo et al., 2019). According to Wurzbacher et al. (2016), freshwater ecosystems are neglected and harbor high microbial diversity. Magwaza et al. (2017), points out that freshwater fungi produce a wide variety of antimicrobial metabolites, which help them to compete against other microorganisms.

Considering the high fungi biodiversity estimates and the notion that only a small fraction of them have been biologically tested for active compounds production, it is evident that there is a great number of bioactive compounds yet to be discovered (Hoeksma et al., 2019). The isolation and identification of new fungal strains are the first steps towards the discovery of new metabolites with antimicrobial activities. This is more imperious for the Amazon region, which has one of the richest biodiversity on the planet but still has insufficient studies to cover all this diversity (Oliveira et al., 2021). In this context, we present an evaluation of antimicrobial and cytotoxic activities of extracts from mycelia of fungi isolated from freshwater samples in the Amazonas state.

\section{Methodology}

\subsection{Fungal material}

In this study, 12 fungal strains isolated from freshwater samples collected from aquatic environments in the State of Amazonas were used. The fungal isolates were obtained from the collection of microorganisms at the Laboratory of Bioassays and Microorganisms of the Amazon of the Federal University of Amazonas (LabMicrA/UFAM), registered under the SisGen (National System for the Management of Genetic Heritage and Traditional Knowledge Associated) with the number: AD64E07. All the strains were previously identified up to genus level by LabMicrA through macro and micro morphological analysis of their structures and by rDNA sequence analysis with an internal transcribed spacer (ITS1-5.8S-ITS2).

\subsection{Production of fungal extracts}

Fungi were reactivated in Petri plates containing PDA+L culture medium (potato, dextrose, and agar, with $0.2 \%$ yeast extract), cultivated at $26^{\circ} \mathrm{C}$ for eight days. After this period, five fragments of $1 \mathrm{~cm}^{2}$ from each fungus culture were inoculated into a $1000 \mathrm{~mL}$ Erlenmeyer containing $300 \mathrm{~mL}$ of PD+L liquid culture medium under sterile conditions (Souza et al., 2004) and maintained at $26^{\circ} \mathrm{C}$, in static mode and in the absence of light.

The cultivation time of each fungus was determined until the glucose level in the culture was consumed. Then, the mycelium was separated from the culture medium by filtration on Whatman paper, $\mathrm{n}^{\circ} 4$. The mycelial mass obtained was covered with a mixture of ethyl acetate and methanol 1:1 (v/v) and kept in maceration for 48 hours, followed by filtration. This process of extraction was repeated more twice every 24 hours. Afterward, the extracts were combined and concentrated in a rotary evaporator at $45^{\circ} \mathrm{C}$. The samples obtained were kept in a desiccator with activated silica to obtain dry mycelial extracts.

\subsection{Antimicrobial assay}

To carry out the antimicrobial assay of the mycelial extracts of the studied fungi, pathogenic strains of bacteria and yeasts obtained from the Cefar Diagnóstica (CCCD) collection were used. Yeasts: C. albicans (CC 001) and C. tropicalis (CC 
002) were reactivated in solid medium Sabouraud (SB) agar (Himedia®), at $36 \pm 1^{\circ} \mathrm{C}$ for 48 hours. Bacteria: Staphylococcus aureus (S 007), Escherichia coli (E 004), Pseudomonas aeruginosa (P 004), and Enterococcus feacalis (E 002) were reactivated in Brain and Heart Infusion (BHI) agar (Himedia $\left.{ }^{\circledR}\right)$, also at $36 \pm 1{ }^{\circ} \mathrm{C}$, but only for 24 hours.

After reactivation of the pathogens, a pure culture of each strain was transferred to a test tube containing $5 \mathrm{~mL}$ of SB broth and BHI broth and kept at $36 \pm 1{ }^{\circ} \mathrm{C}$ for 24 hours. Then, the concentrations of the colonies to be used in the tests was adjusted to achieve $2.5 \times 10^{3} \mathrm{CFU} / \mathrm{mL}$ for yeast (CLSI, 2002) and $5 \times 10^{5} \mathrm{CFU} / \mathrm{mL}$ for bacteria (CLSI, 2003). The samples of the fungi mycelial extracts were weighed and solubilized at a concentration of $2 \mathrm{mg} / \mathrm{mL}$ (stock solution) in $10 \%$ dimethyl sulfoxide (DMSO).

For negative control, 10\% DMSO solution was utilized, and positive control was performed using antibiotics at a concentration of $2 \mathrm{mg} / \mathrm{mL}$, tetracycline for E. coli and P. aeruginosa, ampicillin for S. aureus and E. feacalis, and nystatin for C. albicans and C. tropicalis.

To determine the antimicrobial activity, a screening of the fungal extracts was initially carried out to verify their effectiveness against the tested pathogens. The screening was performed in 96-well Elisa microplates, where it was added in triplicate, $100 \mu \mathrm{L}$ of the culture medium in doubled concentration $(2 \mathrm{x}), 100 \mu \mathrm{L}$ of the stock extract solution $(2 \mathrm{mg} / \mathrm{mL})$, and 10 $\mu \mathrm{L}$ of the pathogen cells suspension to be assayed, reaching a final pathogen concentration of $2.5 \times 10^{3}$ for yeasts and $5 \times 10^{5}$ for bacteria. Finally, the plates were incubated at $36 \pm 1{ }^{\circ} \mathrm{C}$ for 24 hours. After incubation, $10 \mu 1$ of $1 \%$ of a revelator, NBT (Nitroblue Tetrazolium) for fungal and TTC (2,3,5-2,3,5-Triphenyltetrazolium Chloride) for bacteria were added to all wells. When microbial growth occurs, the color in the well changes.

With the positive results of the screening, the successive dilution test was performed to determine the minimum inhibitory dosage (MID). In an Elisa plate were added in triplicate, $100 \mu \mathrm{L}$ of the extract to the first well, with $100 \mu \mathrm{L}$ of the culture medium in doubled concentration $(2 \mathrm{x})$. After homogenization, $100 \mu \mathrm{L}$ was transferred from the first well to the subsequent one (B1, B2, B3), successively performing the dilutions in each well. The extract concentrations obtained after serial dilutions resulted in eight concentrations ranging from 1 to $0,0078125 \mathrm{mg} / \mathrm{mL}$ (CLSI, 2012). The same serial dilution procedure was performed for the positive and negative controls.

Subsequently, $10 \mu \mathrm{L}$ of the pathogen cells suspension was added to all wells to achieve the same concentration as in the screening assay above. The plates were incubated at $36 \pm 1{ }^{\circ} \mathrm{C}$ for 24 hours. After this period, $10 \mu \mathrm{L}$ of $1 \%$ revelators were added: NBT in wells with fungal inoculum and TTC in wells with bacterial inoculum. As a control, $10 \mu \mathrm{L}$ of the tested pathogen cells suspension were inoculated on a plate with a solid medium to verify the microbial growth or its absence, being defined as fungicidal or bactericidal the complete absence of microbial growth and fungistatic or bacteriostatic the reduction of microbial growth.

\subsection{In vitro cytotoxicity assay}

To perform the cytotoxicity assay, the fungal extracts were solubilized in $0.5 \%$ dimethylsulfoxide (DMSO) and tested in eight concentrations, from 50 to $0.39 \mu \mathrm{g} / \mathrm{mL}$. The VERO strain (ATCC ${ }^{\circ}$ CCL-81TM) utilized was acquired from the American Type Culture Collection, grown in Dulbecco's Modified Eagle Medium (DMEM) (Gibco), and supplemented with $10 \%$ inactivated fetal bovine serum (Gibco) and penicillin $(50 \mu \mathrm{g} / \mathrm{ml})$. All tests were performed in triplicate.

Assays were determined by the Alamar Blue method according to Ahmed et al. (1994). The cells suspension was plated at a concentration of $1.0 \times 10^{4}$ cells/well in 96 well Elisa plates and treated with extracts at the determined concentrations, totalizing a final volume of $200 \mu \mathrm{L}$. The plates were kept in a $\mathrm{CO}^{2}$ incubator for 24 hours with $5 \% \mathrm{CO}^{2}$ at 37 ${ }^{\circ} \mathrm{C}$. After this period, $10 \mu \mathrm{L}$ of $0.4 \%$ resazurin (diluted 1:20) was added to each well and the Alamar Blue ${ }^{\mathrm{TM}}$ (Sigma-Aldrich) 
metabolization time of 2 hours was awaited. Fluorescence was monitored in a microplate reader (GloMax® Explorer) with emission of wavelengths between 580 and $640 \mathrm{~nm}$ and an excitation of $520 \mathrm{~nm}$.

The cell growth was used as a positive control, and 0.1\% DMSO was used as a negative control. The percentage of cell viability was calculated according to the formula: $\%$ Viability $=\mathrm{Ft} \times 100 / \mathrm{Fb}$, where $\mathrm{Ft}=($ cell fluorescence + medium + substance + resazurin $)$ and $\mathrm{Fb}=$ (cell fluorescence + medium + resazurin $)$.

The result evaluation was performed according to the criteria established by ISO (2009) - the lower the \% viability value, the higher the cytotoxic potential of the tested material. If the viability is less than $70 \%$, the tested sample has cytotoxic potential.

\section{Results and Discussion}

For the screening assay, all twelve mycelial extracts were tested for antimicrobial activity against six pathogens - two fungi (C. albicans - CC 001 and C. tropicalis - CC 002) and four bacteria (S. aureus - S 007, E. coli - E 004, P. aeruginosa - P 004, and E. feacalis - E 002). No extract showed antibacterial activity and five, representing $41.7 \%$ of the tested extracts showed antifungal activity. The active extracts come from five different fungal genera (Diaporther, Chrysoporther, Aspergillus, Trichoderma, and Fusarium) (Table 1).

Table 1. Antimicrobial activity of mycelial fungal extracts isolated from aquatic environments in the State of Amazonas.

\begin{tabular}{ccccccccc}
\hline \multirow{2}{*}{$\mathbf{N}^{\circ}$} & \multirow{2}{*}{ Fungal strain } & $\begin{array}{c}\text { Code } \\
\text { LabMicrA }\end{array}$ & \multicolumn{7}{c}{ Tested Pathogens } \\
\cline { 4 - 8 } & & 1283 & S 007 & E 004 & P 004 & E 002 & CC 001 & CC 002 \\
\hline 1 & Aspergillus & - & - & - & - & + & - \\
2 & Chrysoporther & 1169 & - & - & - & - & + & - \\
3 & Cladosporium & 1132 & - & - & - & - & - & - \\
4 & Cladosporium & 1135 & - & - & - & - & - & - \\
5 & Cytospora & 1098 & - & - & - & - & - & + \\
6 & Diaporther & 1203 & - & - & - & - & + & - \\
7 & Epicoccum & 1248 & - & - & - & - & - & - \\
8 & Fusarium & 1085 & - & - & - & - & + & - \\
9 & Fusarium & 1280 & - & - & - & - & - & - \\
10 & Sorocladium & 1266 & - & - & - & - & - & - \\
11 & Talaromyces & 1244 & - & - & - & - & - \\
12 & Trichoderma & 1136 & - & - & - & - & + \\
\hline
\end{tabular}

LabMicrA - Collection of microorganisms from the Laboratory of Bioassays and Microorganisms of the Amazon of the Federal University of Amazonas. $(-)=$ no antimicrobial activity; $(+)=$ antimicrobial activity. Bacteria tested: Staphylococcus aureus $(\mathrm{S}$ 007), Escherichia coli $(\mathrm{E}$ 004), Pseudomonas aeruginosa (P 004), and Enterococcus feacalis (E 002). Tested fungi: C. albicans (CC 001) and C. tropicalis (CC 002). Source: Authors.

For the minimum inhibitory dosage (MID) assay, it was observed that five extracts showed fungistatic activity against C. albicans, three at a concentration of $1 \mathrm{mg} / \mathrm{mL}$ (Chrysoporther - 1169, Diaporther - 1203, and Fusarium - 1085) and two at a concentration of $0,25 \mathrm{mg} / \mathrm{mL}$ (Aspergillus - 1283 and Trichoderma - 1136). The extract of Diaporther - 1203 also had fungistatic activity against $C$. tropicalis at a concentration of $1 \mathrm{mg} / \mathrm{mL}$ and the extract of Aspergillus - 1283 showed fungicidal activity against $C$. albicans at a concentration of $1 \mathrm{mg} / \mathrm{mL}$ (Table 2). 
Table 2. Identification of the minimum inhibitory dosage (MID) of mycelial extracts of fungi isolated from aquatic environments in the State of Amazonas against Candida albicans and C. tropicalis.

\begin{tabular}{|c|c|c|c|c|c|}
\hline & Fungal strain & Code & ATMA & Teste & thogens \\
\hline & & & & $\begin{array}{l}\text { Candida albicans } \\
\text { (CC 001) }\end{array}$ & $\begin{array}{c}\text { Candida tropicalis } \\
\text { (CC 002) }\end{array}$ \\
\hline త & Aspergillus & 1283 & + & 0,25 & - \\
\hline$\underline{E}$ & & & ++ & 1 & - \\
\hline$\underline{\Xi}$ & Chrysoporther & 1169 & + & 1 & - \\
\hline 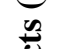 & & & ++ & - & - \\
\hline ల్త్ర & Diaporther & 1203 & + & 1 & 1 \\
\hline$\vec{z}$ & & & ++ & - & - \\
\hline$\frac{\pi}{5}$ & Fusarium & 1085 & + & 1 & - \\
\hline 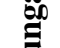 & & & ++ & - & - \\
\hline 呈 & Trichoderma & 1136 & + & 0,25 & - \\
\hline & & & ++ & - & - \\
\hline
\end{tabular}

LabMicrA - Collection of microorganisms from the Laboratory of Bioassays and Microorganisms of the Amazon of the Federal University of Amazonas. ATMA - antimicrobial activity: (+) fungistatic, (++) fungicidal, and (-) without activity. Source: Authors.

In studies investigating metabolites with antifungal activity, an extract having a MIC value of $0,1-1 \mathrm{mg} / \mathrm{mL}$ is considered an effective or significant extract (Simões et al., 2009; Kholoujini et al., 2019). They are called fungicides, extracts capable of causing death of fungus, and fungistatic extracts, those that promote the inhibition of microbial growth (Perussi, 2007). Therefore, five of the mycelial extracts evaluated in this study can be considered extracts with antimicrobial potential.

Diaporthe - 1203 mycelial extract did not show activity against bacterial pathogens. However, it was the only extract with activity against more than one pathogen, showing fungistatic activity against $C$. albicans and $C$. tropicalis. In the study by Dos Reis et al. (2019), Diaporthe extracts also showed antifungal potential, inhibiting the growth of different Candida species. Different results were found by Moreira et al. (2020), in a study in which the fungus Diaporthe showed promising antimicrobial activity against $S$. aureus and $E$. coli but no activity against $C$. albicans. Fungal species of the Diaporthe genus are commonly studied for their ability to generate metabolites with diverse biotechnological applications (Flores et al., 2013; Moreira et al., 2020). Yenn et al. (2017) isolated a new compound (3-hydroxy-5-methoxyhex-5-ene-2,4-dione) with fungicidal activity against $C$. albicans from a Diaporthe strain.

Aspergillus - 1283 mycelial extract showed the best performance in the antimicrobial test, despite also not presenting antibacterial activity. The strain demonstrated fungistatic and fungicidal activity against C. albicans. The results obtained are similar to those found by Sakhri et al. (2019), in which an Aspergillus crebe strain exhibited only antifungal activity when evaluated against the pathogens: E. coli, P. aeruginosa, C. albicans, and C. glabrata. Aspergillus genus has a worldwide distribution and contain a large number of species, which stands out for producing a range of natural products with biological activities (Lotfy et al., 2018), such as asperlicin, echinocandin B, and fumagillin isolated from A. alliaceus, A. nidulans, and A. fumigatus which are used as antifungal, angiogenesis inhibitor, and antiparasitic, respectively (Bracarense \& Takahashi, 2014).

Trichoderma - 1136, Chrysoporthe - 1169, and Fusarium - 1085 mycelial extracts showed only antifungal activity against $C$. albicans. In former reports, Trichoderma species were reported for producing metabolites with activities against different microbial pathogens (Saravanakumar et al., 2018). Chrysoporthe sp. exhibited strong antibacterial activity against $E$. coli and S. aureus (Nirma et al., 2015); and Fusarium species produced metabolites with activities against microbial pathogens (Sibero et al., 2019). Besides, from F. larvarum, an antifungal compound active against C. albicans and a wide range of pathogenic fungi was isolated, called Parafungin (Harvey et al., 2015). 
There is a growing demand for new antibacterial and antifungal compounds due to the constant increase in the number of people with health problems caused by pathogenic microorganisms resistant to existing antimicrobials (Xu et al., 2015; Sanchez \& Demain, 2017). Fungal infections are considered a serious complication of immunosuppression and are associated with substantial utilization of health services and high mortality rates (Sharma \& Chowdhary, 2017).

Microorganisms of the Candida genus are the main agents that cause fungal infections in the bloodstream, known as candidemia. It causes mortality rates varying from 15 to $35 \%$ and increases the period and costs of hospitalization, making the disease a serious public health problem, especially in developing countries (Canela et al., 2021). C. albicans and C. tropicalis are found in the microbiota of the reproductive and gastrointestinal mucosa, living symbiotically in about $50-70 \%$ of healthy individuals (Megri et al., 2020). However, these strains can become pathogenic through changes in the environment or in individuals with weakened immune systems (De Barros et al., 2018). C. albicans is known as the most prevalent cause of candidemia and C. tropicalis is the second most prevalent species in Brazil (Wille et al., 2013; Arastehfar et al., 2020).

According to Kholoujini et al. (2019) there are a small number of studies carried out in search of compounds with antifungal activity compared to the number of studies investigating antibacterial compounds. Considering the increase of fungal diseases, it is relevant to perform more research with this emphasis. As they are considered an important source of bioactive compounds, fungal have been important sources in the pursuit for new antibacterial and antifungal compounds (Sathi et al., 2015; Xu et al., 2015; De Medeiros et al., 2018).

The cytotoxicity assay against VERO cells, according to the criteria established by ISO (2009), showed that 58.3\% of the extracts evaluated in this study had no significant toxic effect on cell viability (Figure 1). Of the twelve fungal mycelial extracts, five (41.7\%) showed cytotoxic potential, with cell viability less than $70 \%$. They belong to the strains Cladosporium 1135, Chrysoporther - 1169, Cytospora - 1098, Fusarium - 1085 and Talaromyces - 1244. 
Figure 1. Cytotoxicity of mycelial extracts of fungi isolated from aquatic environments in the State of Amazonas on VERO cells (ATCC® CCL-81TM).

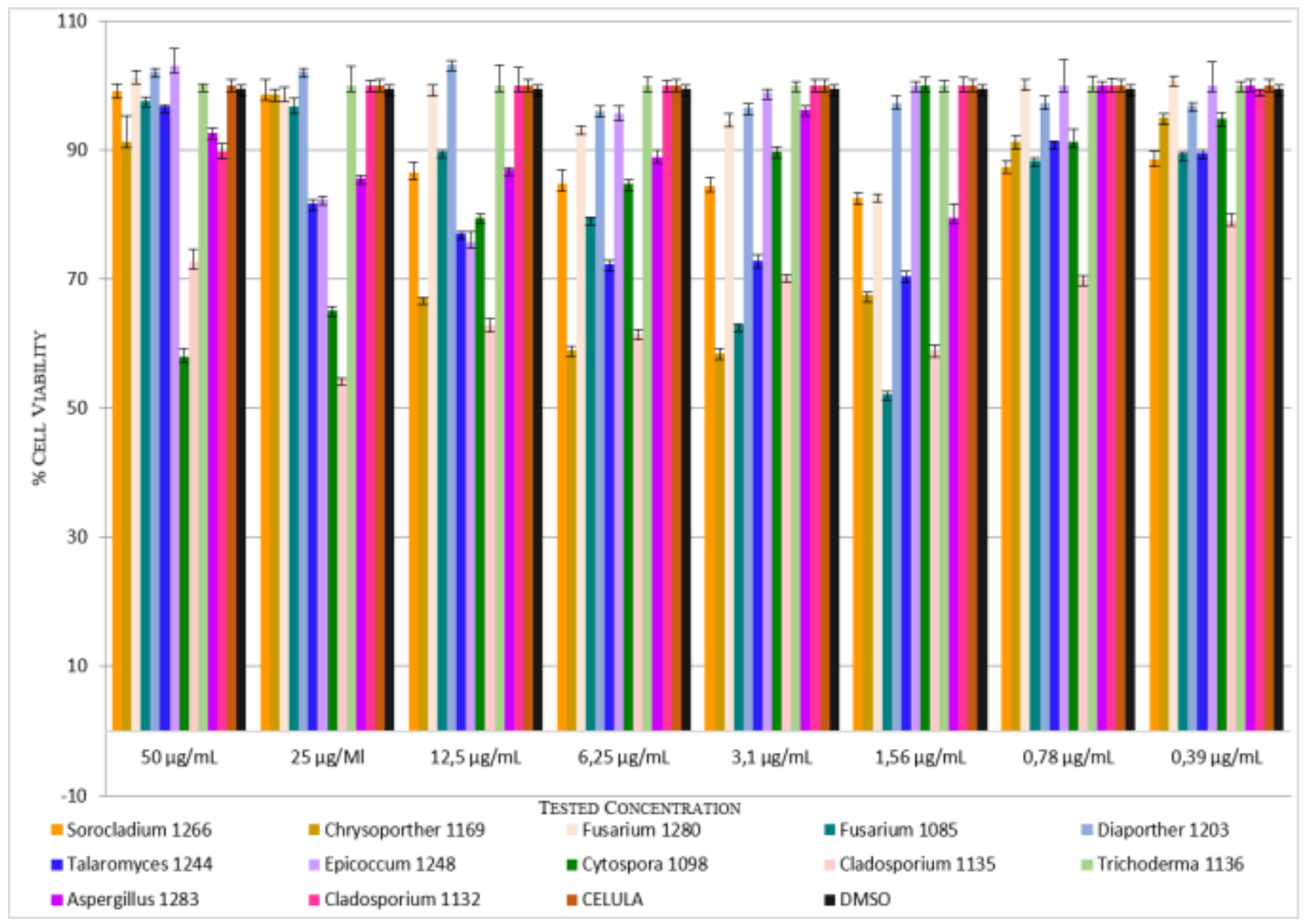

Controls: positive (Cell) and negative (DMSO). Source: Authors.

Saravanakumar et al. (2018) emphasizes that metabolites extracted from fungi in some cases can be naturally toxic, so it is essential to investigate the toxicity of extracts of fungal origin, considering that one of the most important steps during the development of a new drug is the absence of cellular cytotoxicity (Kholoujini et al., 2019). In the present study, considering the five active fungal mycelial extracts only Chrysoporther - 1169 and Fusarium - 1085 showed cytotoxic potential against VERO cells. The other active extracts in the antimicrobial assay showed no cytotoxicity.

\section{Conclusion}

The present study revealed that mycelial extracts from five fungal strains isolated from water samples from the Amazon region, present antimicrobial activity against C. albicans, being one of them also active against C. tropicalis. Among them, only two strains showed cytotoxic potential on VERO cells. The data generated in this study contribute to the knowledge of the antimicrobial and cytotoxic activities of fungi obtained from water samples from the Amazon region. However, further studies aimed at the isolation and identification of bioactive compounds are needed.

\section{Acknowledgments}

The authors appreciate the Coordination of Superior Level Staff Improvement - Brazil (CAPES) - Financial Code 001, 
through the Pró-Amazônia: Biodiversity and Sustainability project, and the Oswaldo Cruz Foundation - Leônidas \& Maria Deane Institute - Manaus/AM.

\section{References}

Ahmed, S. A., Gogal Jr, R. M., \& Walsh, J. E. (1994). A new rapid and simple non-radioactive assay to monitor and determine the proliferation of lymphocytes: an alternative to [3H] thymidine incorporation assay. Journal of Immunological Methods, 170(2), 211-224.

Arastehfar, A., Daneshnia, F., Hafez, A., Khodavaisy, S., Najafzadeh, M. J., Charsizadeh, A., ... \& Boekhout, T. (2020). Antifungal susceptibility, genotyping, resistance mechanism, and clinical profile of Candida tropicalis blood isolates. Medical Mycology, 58(6), 766-773.

Atanasov, A. G., Zotchev, S. B., Dirsch, V. M., \& Supuran, C. T. (2021). Natural products in drug discovery: Advances and opportunities. Nature Reviews Drug Discovery, 20(3), 200-216.

Ayoub, I. M., El-Shazly, M., Lu, M. C., \& Singab, A. N. B. (2014). Antimicrobial and cytotoxic activities of the crude extracts of Dietes bicolor leaves, flowers and rhizomes. South African Journal of Botany, 95, 97-101.

Bracarense, A. A., \& Takahashi, J. A. (2014). Modulation of antimicrobial metabolites production by the fungus Aspergillus parasiticus. Brazilian Journal of Microbiology, 45(1), 313-321.

Canela, H. M. S., Cardoso, B., Frazão, M. R., Falcão, J. P., Vitali, L. H., Martinez, R., \& da Silva Ferreira, M. E. (2021). Genetic diversity assessed using PFGE, MLP and MLST in Candida spp. candidemia isolates obtained from a Brazilian hospital. Brazilian Journal of Microbiology, 52(2), 503-516.

Clinical and Laboratory Standards Institute (CLSI). (2002). Reference method for broth dilution antifungal susceptibility testing of yeasts: approved standardsecond edition. CLSI documents M27-A2. CLSI, Wayne.

Clinical and Laboratory Standards Institute (CLSI). (2003). Methods for dilution antimicrobial susceptibility tests for bacteria that grow aerobically: Approved Standard-Sixth Edition.

Clinical and Laboratory Standards Institute (CLSI). (2012). Performance standards for antimicrobial susceptibility testing, Twenty second Informational Supplement. CLSI document M100-S22. Wayne, PA.

Davies, J., \& Davies, D. (2010). Origins and evolution of antibiotic resistance. Microbiology and Molecular Biology Reviews, 74(3), 417-433.

De Barros, P. P., Rossoni, R. D., Freire, F., Ribeiro, F. D. C., Lopes, L. A. D. C., Junqueira, J. C., \& Jorge, A. O. C. (2018). Candida tropicalis affects the virulence profile of Candida albicans: an in vitro and in vivo study. Pathogens and Disease, 76(2), fty014.

De Medeiros, A. G., Savi, D. C., Mitra, P., Shaaban, K. A., Jha, A. K., Thorson, J. S., ... \& Glienke, C. (2018). Bioprospecting of Diaporthe terebinthifolii LGMF907 for antimicrobial compounds. Folia Microbiologica, 63(4), 499-505.

Dos Reis, C. M., da Rosa, B. V., da Rosa, G. P., do Carmo, G., Morandini, L. M. B., Ugalde, G. A., ... \& Kuhn, R. C. (2019). Antifungal and antibacterial activity of extracts produced from Diaporthe schini. Journal of Biotechnology, 294, 30-37.

Flores, A. C., Pamphile, J. A., Sarragiotto, M. H., \& Clemente, E. (2013). Production of 3-nitropropionic acid by endophytic fungus Phomopsis longicolla isolated from Trichilia elegans A. JUSS ssp. elegans and evaluation of biological activity. World Journal of Microbiology and Biotechnology, 29 (5), 923-932.

Harvey, A. L., Edrada-Ebel, R., \& Quinn, R. J. (2015). The re-emergence of natural products for drug discovery in the genomics era. Nature Reviews Drug Discovery, 14(2), 111-129.

Heo, I., Hong, K., Yang, H., Lee, H. B., Choi, Y. J., \& Hong, S. B. (2019). Diversity of Aspergillus, Penicillium, and Talaromyces species isolated from freshwater environments in Korea. Mycobiology, 47(1), 12-19.

Hoeksma, J., Misset, T., Wever, C., Kemmink, J., Kruijtzer, J., Versluis, K., ... \& den Hertog, J. (2019). A new perspective on fungal metabolites: identification of bioactive compounds from fungi using zebrafish embryogenesis as read-out. Scientific Reports, 9(1), 1-16.

International Organization for Standardization (ISO), UNI EN ISO 10993-5:2009, (2009) "Biological Evaluation of Medical Devices-Part 5: In Vitro Cytotoxicity Testing”, International Organization for Standardization, Geneva, Switzerland.

Kholoujini, M., Shams-Ghahfarokhi, M., Ghiasian, S. A., \& Razzaghi-Abyaneh, M. (2019). Isolation and Evaluation of Antifungal Metabolites from Endophytic Fungi Against Some Pathogenic Fungi. Journal of Biochemical Technology, (2): 97-106.

Lotfy, M. M., Hassan, H. M., Hetta, M. H., El-Gendy, A. O., \& Mohammed, R. (2018). Di-(2-ethylhexyl) Phthalate, a major bioactive metabolite with antimicrobial and cytotoxic activity isolated from River Nile derived fungus Aspergillus awamori. Beni-Suef University Journal of Basic and Applied Sciences, 7(3), 263-269.

Magwaza, N. M., Nxumalo, E. N., Mamba, B. B., \& Msagati, T. A. (2017). The occurrence and diversity of waterborne fungi in African aquatic systems: their impact on water quality and human health. International Journal of Environmental Research and Public Health, $14(5), 546$.

Megri, Y., Arastehfar, A., Boekhout, T., Daneshnia, F., Hörtnagl, C., Sartori, B., ... \& Hamrioui, B. (2020). Candida tropicalis is the most prevalent yeast species causing candidemia in Algeria: the urgent need for antifungal stewardship and infection control measures. Antimicrobial Resistance \& Infection Control, 9, 1-10. 
Moreira, C. C., Luna, G. L. F., Soriano, B., Cavicchioli, R., Bogas, A. E. C., de Sousa, C. P., ... \& Lacava, P. T. (2020). Leishmanicidal, cytotoxic, antimicrobial and enzymatic activities of Diaporthe species, a mangrove-isolated endophytic fungus. African Journal of Microbiology Research, 14(9), 516524.

Nirma, C., Eparvier, V., \& Stien, D. (2015). Reactivation of antibiosis in the entomogenous fungus Chrysoporthe sp. SNB-CN74. The Journal of Antibiotics, 68(9), 586-590.

Oliveira, J., Barreto, A., Silva, L., \& Rhoden, S. (2021). Fungos, diversidade e prospecção no Brasil: Um recurso pouco explorado? Metodologias $e$ Aprendizado, 4, 149-163.

Organização Pan-Americana da Saúde (OPAS). (2020). Resistência antimicrobiana OPAS/OMS|. Organização Pan-Americana da Saúde. https://www.paho.org/pt/topicos/resistencia-antimicrobiana

Perussi, J. R. (2007). Inativação fotodinâmica de microrganismos. Química Nova, 30(4), 988-994.

Premjanu, N., \& Jaynthy, C. (2015). Identification and characterization of antimicrobial metabolite from an endophytic fungus, Colletotrichum gloeosporioides isolated from Lannea corammendalica. International Journal of Chem Tech Research, 7, 369-374.

Sakhri, A., Chaouche, N. K., Catania, M. R., Ritieni, A., \& Santini, A. (2019). Chemical composition of Aspergillus creber extract and evaluation of its antimicrobial and antioxidant activities. Polish Journal of Microbiology, 68(3), 309.

Sanchez, S., \& Demain, A. L. (2017). Bioactive products from fungi. In Food Bioactives (pp. 59-87). Springer, Cham.

Santos, I. P. D., Silva, L. C. N. D., Silva, M. V. D., Araújo, J. M. D., Cavalcanti, M. D. S., \& Lima, V. L. D. M. (2015). Antibacterial activity of endophytic fungi from leaves of Indigofera suffruticosa Miller (Fabaceae). Frontiers in Microbiology, 6, 350.

Saravanakumar, K., Chelliah, R., Ramakrishnan, S. R., Kathiresan, K., Oh, D. H., \& Wang, M. H. (2018). Antibacterial, and antioxidant potentials of noncytotoxic extract of Trichoderma atroviride. Microbial Pathogenesis, 115, 338-342.

Sathi, Z. S., Rahman, M., Faruk, A. L., \& Rashid, M. A. (2015). Antimicrobial susceptibility assessment of compound from Aspergillus fumigatus. African Journal of Biotechnology, 14(3), 167-170.

Sharma, C., \& Chowdhary, A. (2017). Molecular bases of antifungal resistance in filamentous fungi. International Journal of Antimicrobial Agents, 50(5), 607-616.

Sibero, M. T., Igarashi, Y., Radjasa, O. K., Sabdono, A., Trianto, A., Zilda, D. S., \& Wijaya, Y. J. (2019). Sponge-associated fungi from a mangrove habitat in Indonesia: species composition, antimicrobial activity, enzyme screening and bioactive profiling. International Aquatic Research, 11(2), 173-186.

Simões, M., Bennett, R. N., \& Rosa, E. A. (2009). Understanding antimicrobial activities of phytochemicals against multidrug resistant bacteria and biofilms. Natural Product Reports, 26(6), 746-757.

Souza, A. Q. L. D., Souza, A. D. L. D., Astolfi Filho, S., Pinheiro, M. L. B., Sarquis, M. I. D. M., \& Pereira, J. O. (2004). Atividade antimicrobiana de fungos endofíticos isolados de plantas tóxicas da amazônia: Palicourea longiflora (aubl.) rich e Strychnos cogens bentham. Acta Amazônica, 34(2), 185-195.

Wille, M. P., Guimarães, T., Furtado, G. H. C., \& Colombo, A. L. (2013). Historical trends in the epidemiology of candidaemia: analysis of an 11-year period in a tertiary care hospital in Brazil. Memorias do Instituto Oswaldo Cruz, 108(3), 288-292.

Wurzbacher, C., Warthmann, N., Bourne, E. C., Attermeyer, K., Allgaier, M., Powell, J. R., ... \& Monaghan, M. T. (2016). High habitat-specificity in fungal communities in oligo-mesotrophic, temperate Lake Stechlin (North-East Germany). MycoKeys, (16), 17-44.

Xu, L., Meng, W., Cao, C., Wang, J., Shan, W., \& Wang, Q. (2015). Antibacterial and antifungal compounds from marine fungi. Marine Drugs, 13(6), 34793513 .

Yenn, T. W., Ring, L. C., Nee, T. W., Khairuddean, M., Zakaria, L., \& Ibrahim, D. (2017). Endophytic Diaporthe sp. ED2 produces a novel anti-candidal ketone derivative. Journal of Microbiology and Biotechnology, 27(6), 1065-1070. 